\title{
LIBRARIES, SCHOOLS AND MODERN AGE
}

\section{Borjanka Trajković1, Dragana Litričin Dunić}

\author{
Review paper
}

Faculty of Education, Sombor, University of Novi Sad, The Republic of Serbia

Faculty of Teacher Training, Educons University, The Republic of Serbia

Received: 18.02 .2016

UDC: 021

Accepted: 23.03.2016

026/027:37

\begin{abstract}
For centuries the role of the library was defined as a warehouse of books. Now, in the 21st century, the library is facing perhaps the biggest challenge - its physical survival. The role of librarians is re-branded to reflect their expertise as curators of content and reliable navigators in an evergrowing ocean of information - in any format they might exist. The future libraries shall be open to all the new ideas on how to work better and accept the new technologies. On the one hand, they must recognize the need to change their methods, but on the other hand-to preserve the continuity of their objectives and mission. The new era requires modern models of learning and the attractiveness of the curricula, that is, a modern education system that shall adapt the curricula to the needs of modern society and reconcile centuries of man's need for knowledge, reading books and education in general with the new technologies.
\end{abstract}

Key words: library, books, communication, reader, school, modern age.

\section{INTRODUCTION}

For centuries the role of the library was defined as a warehouse of books. Now, in the 21 st century, the library is facing perhaps the biggest challenge - its physical survival. In the article Libraries reinvent themselves for the 21st century (Mullaney, 2013) Tom Mullaney points out that Americans are increasingly moving away from the printed page and turn to digital screens for information and communication. Libraries have been adapting to this shift redefining the function of a library as engaged social center. The role of librarians is re-branded to reflect their expertise as curators of content and reliable navigators in an evergrowing ocean of information - in any format they might exist. What illustrates how the world has rapidly and dramatically changed is the fact that the ten most wanted professions on the planet Earth in 2010 did not even exist in 2004. According to a research by the UK Government on the most desirable jobs among young people, the results which were published in 2015, the list of the most desirable jobs is as follows: 1. Author, 2. Librarian, 3. Professor, 4. Lawyer, 5. Interior designer, 6. Journalist, 7. Doctor, 8. TV presenter, 9. Train driver, 10. Teacher. What encourages is the fact that librarians take a very high place on the list of desirable professions.

\footnotetext{
${ }^{1}$ Correspondence to:

Borjanka Trajković, PhD, University of Novi Sad, Faculty of Education

Sombor, The Republic of Serbia

Phone: +381638797608

E-mail: trajkovic.bor@sbb.rs
} 
For the future libraries it is most important to stay true to their original aims, objectives and values. Crawford Walt and Michael Gorman in their book Future Libraries: Dreams, Madness, and Reality (Chicago [etc.]: American Library Association, 1995), highlight four ideas that should not be forgotten by any library in the information society:

1. The first reason for the existence of libraries is humane provision of services to human beings and the human community.

2. Knowledge and understanding, rather than data or information must remain the central concern of the library community.

3. The basic ethical principles of librarianship are cooperation, equal access to the collections and services and intellectual freedom.

4. Librarians should be proud of their mission which they have been meeting for centuries and aware of its weight and responsibility.

\section{OBSERVATIONS}

Librarians must resolutely defend the eternal purpose of libraries - the collection, preservation, organization and dissemination of records of knowledge and information of the human race and the provision of services based on these records. Moreover, they need to defend and in their own example show the key values on which the culture of library is built - community, literacy, learning, service, understanding, democracy and intellectual freedom. From ancient Egyptian Library of Alexandria to the present day, libraries have been a kind of social legitimacy of communities that have based their identity on cultural knowledge. Therefore, their mission will remain unchanged in the dynamic world of high information technologies: to support humanity and democratic development of society through the free access to public knowledge. We shall agree that the tasks of librarians do not change, but the means and processes used in performing tasks change rapidly. "The mission of libraries today and the broad tasks of librarians have far more in common with the libraries and librarians from the 19th century than with the computer center," says the American theorist Michael Gorman in his book Our Everlasting Values: Library in the 21st Century. The rapid growth of electronic resources available to libraries and automated library processes have only increased the efficiency of library services. The stories of "virtual" or "digital" library as a replacement for the traditional one have been diminishing and there have been less and less of those who claim that "digital" books will replace the printed ones. (Gorman, 2007).

The task of the librarians is knowledge management and library is postulated as a social epistemology or theories about the methods and the foundations of human knowledge, particularly when it comes to borders, values, use and application of knowledge within a society or culture.

American theorist Jesse Hauk Shera concludes that a library should be much more than the sum of skills and procedures for finding specific books on a particular shelf for a specific user with a specific request, if it is, with all its resources, in the service of social development. It is certain that a library must include the aforementioned procedures, but it is essentially something more - knowledge management, with the aim for a man to use it to understand the world in which he lives more profoundly. The way in which human knowledge is institutionalized and socialized, as well as the ways in which society coordinates the knowledge and use it, are still unrecognized and underdeveloped fields of research. This is where we should use social epistemology or a new library system as a theoretical and practical discipline that deals with the interaction of knowledge and social activities and the capabilities of their quality synthesis. Professor of library science from Sofia University, Marija Mladenov, said that "humanism lays the foundation for libraries, library work, our profession and librarianship as a science, the subject of which is library as rounded an integrated system consisting of four interrelated elements: the library fund, the reader, the material-technical base and library staff. Therefore, we can certainly say that the history of library primarily teaches us a humane treatment of the libraries as an important part of world heritage, according to our readers and the humanist character of our profession, which makes a significant contribution to the development of world culture and civilization."(Mladenova, 2014).

In the book Library and Identity we read the exact observations that "the act of reading, no matter how free and individual it was, actually connects us with the world, with other people, creating the imaginary or, less frequently, real communities of readers who share the same experience of the world, the same or similar beliefs, values, ideals and hopes. At the same time libraries can help in the creation of personal and collective identity ..."(Stokić-Simončić \& Vučković, 2012:12). 
Advances in technology have contributed to new and different habits of young people, but the need for the world of literature and all the spiritual knowledge and pleasures that it provides can not be suppressed by the rapid technological development.

When it comes to pleasure in the text, one can not overlook the famous Barthes's thoughts: "Pleasure of the text. Classics. Culture (the more culture, the greater, more diverse, the pleasure will be). Intelligence. Irony. Delicacy. Euphoria. Mastery. Security: art of living. The pleasure of the text can be defined by praxis (without any danger of repression): the time and place of reading: house, countryside, near mealtime, the lamp, family where it should be, i.e., close but not too close (Proust in the lavatory that smelled of orrisroot), etc." (Barthes, 2010: 133).

The thesis that the "digital" books will replace the printed one has been increasingly called into question. However, the book has survived for centuries and shall last and in this and all other times, in the old and the new, for instance, electronic forms.

\section{CONTEMPORARY COMMUNICATION AND MODERN SCHOOL}

One of predominant research tasks nowadays is to thoroughly analyse teaching as a basic educational process and to find new formulae for a twenty-first century child who uses information technologies as major communication means.

The new era requires modern models of learning and the attractiveness of the curricula, that is, a modern education system that shall adapt the curricula to the needs of modern society and reconcile centuries of man's need for knowledge, reading books and education in general with the new technologies.

All these should contribute to the individualization of learning and development of students' personal potentials and consequently the development of new ideas which would actively improve new knowledge. We live in the "knowledge century", the "new information civilization", the "learning society", " network society", "digital renaissance", with the application of "intelligent technology education and intelligent learning environment", "multimedia technology", technology of interactive learning, etc.

Today, when modern technology is everpresent, it is applied in education as well. What we can certainly state is that the use of modern technologies can improve the quality of teaching which should contribute to more creative and comprehensive education, pro- vide permanent feedback of the student's activity and inspire the cooperative relationship between students and teachers, thus offering the utilization of databases and information.

The teachers are no longer the only source of knowledge and information, nor is the school the only center of learning and development of young people. Internet is a universal system of modern information and communication to unprecedented levels, and it updates, supplements and expands the facilities and opportunities of textbooks, teaching and learning. A book, as previously mentioned, is still important, but not as the only teaching means, because new models of learning make it possible to create more effective teaching practice.

Computer and multimedia application itself is extremely motivational learning tool. It can be applied through the implementation of the content of school subjects through: pair work, work in a smaller or larger group, individual work, free time activities.

Naturally, a school should not be subordinated to technology but help students understand its possibilities and limitations, and use it in the most appropriate manner.

\section{Key questions}

However, there are issues in the learning process: how available is the new technology and how much we know how to use the modern technology, how creatively teachers approach to the class organization? The new didactic theories increasingly insist on the teaching process, which will be highly interactive and there will be more learning and less teaching. Mere possession of a complete understanding of modern technologies is a prerequisite for progress, and modern society already has it, so therefore the task of a trainer is made easier.A survey was conducted in a small town in Serbia. The aim of this research was to determine students' interest in modern technology, and thus the possibility to use this technology in the curriculum to make it more interesting.

A great interest has been noticed among the 4th grade primary school students in the use of modern technologies in class, but what we have also noticed is a difficult economic situation in the schools, which has lead to them being modestly or insufficiently equipped with computers. Therefore, they have not been able to apply the multi-media material in class, while the teachers were not familiar enough with these methods. This phenomenon can be seen in the less developed regions of the country. 
It was noted that in the modern education the technological development patterns are not homogenized in each school equally within education and we do not have the opportunity to apply the same technology in every school.

\section{CONCLUSION}

Modern information technology has imposed a great number of new challenges for teachers who are expected to permanently follow and improve new methods by using interesting and miscellaneous teaching materials.

Multi-channel electronic connections between teachers and students allow the teacher and student to communicate faster, but the question is whether the quality is better, although it is certain that through the computer it is allowed that all the information prepared immediately cand be directed to any part of the world and also that the data bases from any part of the world could be used. The technology can not be expected more than what it can give, but no less than what it is objectively capable of.

There is no application of an information paradigm without equipping the schools and training the teachers to effectively use the modern equipment. The teacher has a significant role in teaching process, and his/her interaction with students includes development of their individual potentials and critical thinking.

Technological development is not equal, however, and the teaching process in many developing nations or rural schools implies the necessity of traditional learning methods and return the book as a centuriesold and unsurpassed knowledge means. The technology, according to many studies, is not enough put into the service of education and has not merged in the right way what was for centuries justified as a supreme value - specifically, for example, when it comes to literature, to introduce the rich literary treasures to the 21 st century children.

The future libraries shall be open to all the new ideas on how to work better and accept the new technologies. On the one hand, they must recognize the need to change their methods, but on the other hand - to preserve the continuity of their objectives and mission.

\section{REFERENCES}

Bart, R. (2010). Zadovoljstvo u tekstu i Varijacije u pismu. Beograd: Službeni glasnik

Brophy, P. (2006). Measuring library performance. London: Facet

Cronin, B. (1986). The information society. Aslib proceedings, 4

Gorman, M. (1995). Future libraries: dreams, madness and reality. Chicago: ALA

Mladenova, M. (2014). Čemu nas uči biblioteka?http://citaliste. rs/casopis/br18/mladenova_marija.pdf (accessed on May 4th 2014)

Mullaney, T. (2013). Libraries reinvent themselves for the 21st century. Accesed on Oct 14th 2015 at http://www. chicagotribune.com/features/books/chi-library-future-20131212,0,2880286.story

Shera, J. H. (2005). Libraries and the organization of knowledge. Hamden: PLA

Stokić Simončić, G. \& Vučković, Ž. (2012). Biblioteka i identitet. Pančevo - Novi Sad: Gradska biblioteka Pančevo Filozofski fakultet Univerziteta u Novom Sadu 